\title{
CONSTRUCTIVE TRUSTS AND THE HOMEMAKER
}

\author{
Sarah Greer* and Mark Pawlowski ${ }^{* *}$
}

\begin{abstract}
To what extent, following the decisions in Stack $v$ Dowden ${ }^{1}$ and Abbott $v$ Abbott, ${ }^{2}$ may a claimant acquire beneficial ownership in the family home under a constructive trust relying purely on domestic contributions as homemaker? The writers examine this question against the background of single and joint ownership cases and suggest that, in the light of recent judicial pronouncements, the criteria for establishing a common intention constructive trust enunciated by Lord Bridge in Lloyds Bank plc $v$ Rosset $^{3}$ may have been eroded so as to allow for a much broader inquiry of the claimant's contributions to support a constructive trust. In particular, it is submitted that this may allow the English courts to consider the same factors for both establishing and quantifying the claimant's interest in the property which, in turn, may pave the way for a closer assimilation between single and joint ownership cases in this field.
\end{abstract}

\section{INTRODUCTION}

This year, the landmark case of Lloyds Bank plc v Rosset ${ }^{4}$ comes of age. In Rosset, the House of Lords set a framework for ascertaining equitable ownership in the family home by means of a common intention constructive trust. In the 18 years since the decision, the social circumstances underpinning the case have continued to evolve. Unsurprisingly, the Rosset ruling has come under increasing attack, either by courts seeking to interpret its guidelines

\footnotetext{
* Barrister, Teaching Fellow in Law, Department of Law, University of Greenwich.

** Barrister, Professor of Property Law, Department of Law, University of Greenwich.

1 [2007] UKHL 17, HL.

2 [2007] UKPC 53, PC.

${ }^{3}$ [1991] 1 AC 107, HL.

4 [1991] 1 AC 107, HL.
} 
creatively ${ }^{5}$ or more directly, as in the equally significant House of Lords' decision in Stack $v$ Dowden. ${ }^{6}$

Rosset concerned a wife attempting to defeat a third party creditor by means of an overriding interest under s 70(1)(g) of the Land Registration Act $1925 .^{7}$ In order to establish such a claim, she had first to demonstrate that she had acquired an equitable interest in the property which was registered in the sole name of her husband. Mrs Rosset had not made any financial contribution to the purchase price of the property, nor had there ever been any express discussions between her and her husband as to the beneficial ownership of the property. ${ }^{8}$ Lord Bridge delivered the leading speech and, after reviewing the authorities, identified two categories of common intention constructive trust, either of which, if established, would give a claimant an equitable interest in the property. The first is an express common intention constructive trust, based on actual discussions between the parties. Unfortunately for Mrs Rosset, the lack of express discussions closed this route of establishing such an equitable interest. Lord Bridge then went on to describe the circumstances in which the court could infer a common intention between the parties based on the conduct of the parties. In this situation, according to his Lordship, only direct financial contributions to the initial purchase price or subsequent mortgage instalments would suffice to support equitable entitlement. In Mrs Rosset's case, such contributions were absent and her involvement in the subsequent improvement of the property was characterised as trivial and insignificant. Her claim was, therefore, dismissed. ${ }^{9}$

A similar problem is frequently encountered by a cohabitant who is seeking to establish an equitable share in the family home following a separation. The most celebrated example is to be found in Burns $v$ Burns, ${ }^{10}$ where the claim also failed. Here, the female claimant had made no financial contributions towards purchase or mortgage payments but had contributed to housekeeping, children's expenses and general domestic expenditure including the purchase of several domestic appliances. Although the couple had lived together for 19 years and had two children together, the Court of Appeal rejected Mrs Burns' claim to beneficial entitlement based solely on

\footnotetext{
${ }^{5}$ See, Le Foe v Le Foe [2001] 2 FLR 970.

${ }^{6}$ [2007] UKHL 17, HL.

${ }^{7}$ Now Sch 3, para. 2 of the Land Registration Act 2002.

8 Indeed, the trustees of the husband's family trust fund stipulated that the trust monies would only be released if the property was acquired in the sole name of the husband.

${ }^{9}$ Mrs Rosset may have had a claim in family law against Mr Rosset, but in this case it was important that she could claim that she had an interest in equity which bound the bank.

${ }^{10}$ [1984] Ch 317, CA.
} 
her domestic contributions as homemaker. ${ }^{11}$ That was a decision made back in 1984 and the interesting question (posed throughout this article) is whether the Burns-type claimant would fare any better in the light of more recent English authority, which suggests that, in the words of Lord Walker ${ }^{12}$ in Stack, "the law has moved on" since Rosset.

\section{EXPRESS DECLARATION OF TRUST}

The most sensible approach for cohabiting partners to avoid disputes is to reach an agreement as to the beneficial interests in the property before purchase. This decision can then be recorded during the conveyancing process on the HM Land Registry TR1 Form. This asks the prospective purchasers whether they wish to hold in equity as joint tenants or tenants in common and, if the latter, asks them if they wish to hold in equal shares. If they wish to hold the beneficial interest other than equally, there is an opportunity to specify the proportionate shares agreed. Despite widespread concern, however, the Land Registry has decided not to make this question compulsory in the recent reform of Land Registry forms. ${ }^{13}$ Indeed, many couples choose not to answer the question because they find it unpleasant to consider the end of a relationship at a time when they are living together happily. ${ }^{14}$

Where the parties go ahead and execute a trust expressly declaring their respective beneficial interests ${ }^{15}$ in the property, this will be conclusive of the parties' common intention in the absence of some vitiating factor (e.g., misrepresentation, mistake ${ }^{16}$ or undue influence). In other words, the size of the parties' respective shares will be determined according to the terms of their express trust regardless of their actual contributions to the purchase of

\footnotetext{
${ }^{11}$ See also, Midland Bank plc v Dobson [1986] 1 FLR 171 CA, where Mrs Dobson had used part of her earnings for household expenses, including the purchase of domestic equipment and did some ordinary periodic decorating. She also looked after the home and the parties' two children. The Court of Appeal held that there was no nexus between her carrying out these household duties and the acquisition of the property.

12 Ibid, at para 26.

${ }^{13}$ Explanatory Memorandum to the Land Registration (Amendment) Rules 2008. The Law Society opposed the suggestion that completing the TR1 should be compulsory.

14 See further, Douglas, Pearce and Woodward, "Cohabitation and Conveyancing Practice: Problems and Solutions” [2008] Conv. 365.

${ }^{15}$ It should be noted, however, that an express trust may not declare the beneficial shares but merely state the intention to hold on trust.

${ }^{16}$ Bhatt v Bhatt, 3 April 2009, unreported, available on Lawtel. See also, A Chandler, "Express Declarations of Trust, Rectification and Rescission: Goodman v Gallant Revisited” (2008) 38 Family Law 1210.
} 
the property. ${ }^{17}$ A Burns claimant, therefore, who has made no financial contribution towards acquisition, will, nevertheless, be entitled to a beneficial share corresponding to that agreed between the parties and evidenced by their declaration of trust. ${ }^{18}$ Moreover, an express declared trust precludes the possibility of a supervening constructive or resulting trust based on subsequent differential contributions until the declared trust is varied by subsequent agreement. ${ }^{19}$

What, however, is the position where no formal trust is executed declaring the equitable ownership of the property? In this scenario, the cohabiting couple must rely on equity to resolve their difficulties. The route to be taken when cohabiting partners disagree about beneficial interests in the family home, depends primarily on whether, as in Rosset or Burns, the property is registered in the sole name of one of the partners, or the parties are joint registered proprietors, as in Stack. It will be convenient, therefore, to examine single and joint ownership cases separately.

\section{SINGLE OWNERSHIP CASES}

\section{Express common intention}

It is conceivable that purely domestic contributions as homemaker may be enough to avail a claimant in establishing a common intention at the primary stage of the court's inquiry, where he (or she) relies on express discussions between the parties as to their beneficial ownership. In the express common intention category, the court is not obliged to look for conduct from which an intention can be inferred, but only for conduct which "amounts to an acting upon it by the claimant". ${ }^{20}$ In other words, in the express category, the common intention is already present and claimant's conduct is only relevant to satisfy the requirement of detriment. Thus, in Rosset, Lord Bridge ${ }^{21}$ refers to detriment or a "significant alteration of position" in reliance on the

\footnotetext{
${ }^{17}$ Goodman v Gallant [1986] Fam 106.

${ }^{18}$ See, for example, Turton $v$ Turton [1988] Ch. 542 and Wright $v$ Johnson [2002] P \& CR 210. An express declared trust of land must be "manifested and proved by some writing" in order to comply with the legal formalities set out in s 53(1)(b) of the Law of Property Act 1925.

${ }^{19}$ See, Goodman v Gallant [1986] Fam 106, per Slade LJ: "if the relevant conveyance contains an express declaration of trust which comprehensively declares the beneficial interests in the property or its proceeds of sale, there is no room for the application of the doctrine of resulting, implied or constructive trusts unless or until the conveyance is set aside or rectified.” See also, Pink v Lawrence (1977) 36 P \& CR 98, at 101, per Buckley LJ

${ }^{20}$ See, Grant v Edwards [1986] 1 Ch. 638, at 647, per Nourse LJ.

${ }^{21}$ [1991] 1 AC 107 at 132.
} 
common intention. In this connection, the relevant conduct will often involve the incurring of expenditure which is referable to the acquisition of the house, but it need not necessarily always take this form. ${ }^{22}$

Let us suppose that, in Burns, the parties had expressly agreed that, despite the house being placed in the male partner's sole name, the female partner was to have some share in the beneficial interest so as to reflect her contribution towards the care and upkeep of the family. If Mrs Burns had then acted on the faith of that common intention (by staying at home in order to act as homemaker and carer), would she be entitled to a proprietary interest in the house under an express common intention constructive trust? In Grant $v$ Edwards, the Court of Appeal expressed a difference of opinion as to what would qualify as conduct amounting to detriment in this category. Nourse LJ opined that the conduct must be such that the claimant could not reasonably have expected to embark upon unless she was to have an interest in the house. $^{23}$ His Lordship held that the claimant's contribution to housekeeping expenses constituted an indirect financial contribution to the mortgage payments in so far as it enabled her male partner to pay them out of his own earnings. There was, therefore, in his view, a sufficient link between the contribution to housekeeping and the acquisition of an interest in the house. On the other hand, Sir Nicholas Browne-Wilkinson suggested that:

“....any act done by [the claimant] to her detriment relating to the joint lives of the parties is . . . sufficient to qualify. The acts do not have to be inherently referable to the house."24

His Lordship noted that, in many cases, it may prove impossible to apply the test suggested by Nourse LJ because acts such as homemaking and child care may be linked to motives of affection as well as an intention to acquire an interest in the property. The two were, therefore, inevitably interlinked. On Sir Nicholas Browne-Wilkinson's more relaxed formulation in Grant, however, such conduct would presumably qualify as "any act done by her to her detriment relating to the joint lives of the parties" ${ }^{25}$ notwithstanding that it

\footnotetext{
${ }^{22}$ See, for example, Levi v Levi, March 12 2008, unreported, available on Lawtel, where an open-ended loan at an uncommercially low level of interest was held to amount to sufficient detriment to support an express common intention constructive trust. The deputy judge concluded (at para 56) that "detriment need not be great where there is an express agreement ...”

${ }^{23}$ Ibid, at 648 .

${ }^{24}$ Ibid, at 657.

${ }^{25}$ Ibid, at 657.
} 
was not, strictly speaking, referable to acquisition of the house. ${ }^{26}$ Indeed, his Lordship refers specifically to "contributions by way of labour or other unquantifiable actions" as being relevant. ${ }^{27}$ This view is reinforced by the notion that, in the express common intention category, detriment should be seen as broadly equivalent to that required to support a claim in proprietary estoppel. ${ }^{28}$ It should be stressed, however, that although detriment may have been more loosely interpreted in this way, its relevance (in the orthodox sense) only becomes significant if the court has proof of express discussions between the parties as to their beneficial entitlement.

\section{Inferred common intention}

In the absence of any finding of an agreement or arrangement between the parties to share beneficially, the court relies on the parties' conduct both as a basis from which to infer a common intention and as the detrimental conduct relied on to give rise to a constructive trust. ${ }^{29}$ Unlike the express common intention category, therefore, the relevant conduct serves a dual purpose when determining whether the claimant has surmounted the first hurdle of establishing a constructive trust under Lord Bridge's scheme in Rosset.

In this situation, the court has to look for "expenditure which is referable to the acquisition of the house". ${ }^{30}$ Thus, direct contributions to the purchase price, whether initially or by payment of mortgage instalments, will readily suffice. It is now also apparent (despite Lord Bridge's apparent observations to the contrary in Rosset) that indirect contributions (in the shape of contributions to general household expenses thereby releasing the other party's income to pay the mortgage instalments) may be capable of supporting a claim to a beneficial share under an inferred constructive trust. ${ }^{31}$

\footnotetext{
${ }^{26}$ In Rosset, Lord Bridge seems to accept this more relaxed formulation in so far as he refers to a mere "significant alteration in position" as supporting an express common intention: [1991] 1 AC 107 HL, at 137.

${ }^{27}$ Ibid, at 657.

${ }^{28}$ Significantly, in Rosset, Lord Bridge makes reference to the express category as giving rise to both a constructive trust and proprietary estoppel. In Grant, Sir Nicholas Browne-Wilkinson V-C, considered that "useful guidance" could be obtained from proprietary estoppel cases in this context: ibid, at 656 .

${ }^{29}$ See, Grant v Edwards [1986] 1 Ch. 638, at 647, per Nourse LJ.

${ }^{30}$ Ibid, at 647.

${ }^{31}$ Le Foe v Le Foe [2001] 2 FLR 970. Interestingly, Lord Walker in Stack v Dowden [2007] UKHL 17, at para. 26, has added to the debate by expressly doubting whether Lord Bridge's observation on this point "took full account of the views . . . expressed in Gissing v Gissing." His Lordship noted that this observation had "attracted some trenchant criticism" from academics as potentially productive of injustice.
} 
It is insufficient, however, according to Burns, for the claimant to contribute merely towards household expenses simpliciter, purchase furniture or electrical appliances, or to do the housework, decorating or gardening, since such conduct does not manifest an intention of assisting the purchase of the house and, therefore, with the aim of acquiring some interest in the property. The reasons for this restrained approach are twofold. First, as mentioned earlier, it may be impossible to say whether or not the claimant would have done the acts relied on as detriment even if she thought she had no interest in the house. Conduct such as setting-up house together, having a baby, making payments to general household expenses (which are not strictly necessary to enable the mortgage to be repaid) and looking after the family are all treated as potentially referable to the mutual love and affection of the parties and not specifically referable to the claimant's belief that she has an interest in the property. This approach is typified by the following remarks of Fox LJ in Burns ${ }^{32}$ :

“...the fact that the parties lived together and do the ordinary domestic tasks, is, in my view, no indication at all that they thereby intended to alter the existing property rights of either of them... The undertaking of such work is, I think... the sort of things which are done for the benefit of the family without altering the title to the property."

An assertion that spousal and domestic services can alter property rights is seen essentially, as reverting to the idea of the "family asset", which has been consistently rejected by the English courts, including the House of Lords in Pettit $v$ Pettit ${ }^{33}$ and Gissing $v$ Gissing. ${ }^{34}$ Secondly, it is also apparent that the English judiciary are mindful of the fact that the wide powers conferred by the Matrimonial Causes Act 1973, in relation to the property of married persons, do not apply to unmarried couples. Hence, the court's reluctance to take on board a broader-based jurisdiction to re-allocate property rights of de facto partners in the absence of specific statutory intervention. ${ }^{35}$

Significantly, his Lordship felt that, regardless whether Lord Bridge's view was justified in 1990, the law had now moved on.

${ }^{32}$ Burns v Burns [1984] Ch. 317, CA, at 331. See also, May LJ, at 345. See also, more recently, James v Thomas [2007] EWCA Civ 1212; Morris v Morris [2008] EWCA Civ 257 and Thomson v Humphrey [2009] EWHC 3576 (Ch).

33 [1970] AC 777, HL

34 [1971] AC 886, HL

35 See, the remarks of May LJ in Burns v Burns [1984] Ch 317, at 333: "In my view, as Parliament has not legislated for the unmarried couple as it has for those who have been married, the courts should be slow to attempt in effect to legislate themselves.” 
This stance has been reaffirmed most recently in Stack, where Lord Neuberger made clear that mere payments towards household bills and outgoings, or merely living together for a long time, or having children would not by themselves support an intention to alter beneficial entitlement where the parties had purchased the property in joint names. Such matters, in his view, were only relevant as "part of the vital background" in the sense of providing the context by reference to which any discussions or actions, subsequent to purchase, fell to be assessed by the court. Presumably, the same approach (subject to what is said below) continues to apply to single ownership cases so that Burns remains good law in the context of a nonowning claimant who seeks to claim a beneficial share based solely on homemaker contributions where there is no formal declaration of trust or evidence of any express discussions between the parties as to beneficial ownership.

\section{BLURRING THE BOUNDARIES}

The speeches in Stack, however, also evidence some blurring of the distinct boundaries between Lord Bridge's rigid categorisation of common intention (whether express or inferred) and detriment in single ownership cases. On a liberal reading of the speeches of Lord Walker and Baroness Hale, in particular, there is some scope for arguing that domestic and spousal services now rank not only as factors in assessing the quantum of the parties' beneficial interests but as contributions referable per se to the initial (or threshold) question as to whether there is the requisite common intention to support a constructive trust in the first place. Lord Walker makes specific reference to Lord Bridge's speech in Rosset stating that: "the law has [since] moved on" and suggesting that the House of Lords "should move it a little more in the same direction". ${ }^{36}$ Later in his speech, he refers to the need to take "a wide view of what is capable of counting as a contribution towards the acquisition of a residence". ${ }^{37}$ This statement, however, appears to have been made in the context of the factors relevant to the question of quantification of the parties' respective beneficial shares and not with specific reference to Lord Bridge's second category of constructive trust in Rosset. Baroness Hale, on the other hand, after recognising that that "we are not in this case concerned with the first hurdle", acknowledges that "there is undoubtedly an argument for saying that ... the observations, which were strictly obiter dicta, of Lord Bridge ... have set the hurdle rather too high in certain respects." ${ }^{38}$ In her view, however, the point did not arise for consideration because a

\footnotetext{
${ }^{36}$ Stack v Dowden [2007] UKHL 17, at para 26.

${ }^{37} \mathrm{Ibid}$, at para. 34.

${ }^{38}$ Ibid, at para. 63.
} 
conveyance into joint names (as in Stack) was sufficient in the majority of cases to surmount the first hurdle. Lord Neuberger, on the other hand, although recognising that it may be difficult in the abstract to identify the factors which can be taken into account to infer a common intention under the first hurdle, specifically refers to events occurring after the acquisition of the house which may alter the beneficial interests under the trust arising initially at the date of acquisition. In this connection, he mentions a significant improvement to the home (the cost being seen as a capital expenditure) as justifying an adjustment of the parties' beneficial ownership. On the other hand, as noted earlier, mere payments towards household bills and outgoings, or merely living together for a long time, having children would not, in his view, by themselves support an intention to alter equitable entitlement.

The first significant single ownership case after Stack was a Privy Council decision, Abbott $v$ Abbott, ${ }^{39}$ with Baroness Hale once more delivering the leading judgment. Here, the Privy Council considered an appeal from the Court of Appeal of Antigua and Barbuda in respect of a wife's claim for an equitable interest in the family home which had been conveyed into the husband's sole name. Counsel on both sides unsurprisingly based their arguments on Rosset. Baroness Hale criticised the Court of Appeal for attaching "undue significance" to Lord Bridge's dictum as to what contributions would qualify in the inferred common intention category and approached the issues of establishing and quantifying the equitable interest in a more robust way. The facts in Abbott would have allowed Baroness Hale to confirm that a constructive trust had indeed arisen in either of Lord Bridge's categories. The husband agreed that the wife was entitled to an equitable interest in the family home (express common intention), and the wife had also made a direct financial contribution to the property via, inter alia, half of a wedding gift given to the couple (inferred common intention). Rather than focusing on either of these, however, Baroness Hale's judgment suggests a more flexible route to establishing a common intention constructive trust, This involves taking into account the "parties' whole course of conduct in relation to the property... in determining their shared intentions as to its ownership." ${ }^{40}$

Her Ladyship looked, in particular, at the behaviour of the parties during their marriage. In this connection, the couple organised their finances entirely jointly; they were jointly liable on the mortgage and had a joint bank account from which the loan repayments were made. She decided that this was evidence to support the conclusion that the parties' common intention was to acquire an equitable interest in the property. This approach is interesting because, although such domestic details were used in Stack in the process of quantifying the parties' shares in a joint ownership situation, in Abbott, the

\footnotetext{
39 [2007] UKPC 53.

${ }^{40}$ Ibid, at 19
} 
Privy Council used them to justify the acquisition of an equitable interest, with little or no reference to Lord Bridge's familiar two-part test.

The question then is - can the Abbott approach assist the Burns-type claimant? It is submitted, cautiously, that it may. Although in Abbott, as in Stack, the court concerned itself primarily with the parties' financial - rather than domestic - arrangements, Baroness Hale makes clear that the parties' "whole course of conduct in relation to the property" should be considered in determining their shared intentions. In particular, she listed a number of factors (other than just financial contributions towards the initial purchase or subsequent mortgage) which would be relevant including, notably, how the parties had agreed to arrange their finances and discharge the outgoings and household expenses. Her Ladyship also referred specifically to the question of whether the parties had children for whom they both had responsibility to provide a home. It is possible, therefore, in the future, that in single ownership cases, a claimant who has foregone paid employment to look after the home (Burns) or to renovate it (Rosset) may be more successful in establishing an equitable interest under this more relaxed route involving essentially the assimilation of the Rosset two-part test into just one composite inquiry into the parties' whole course of dealings in relation to the property. It is submitted that the primary question in all such cases is the determination of the parties' true intentions and, as Baroness Hale herself makes clear in Stack, this can only be properly determined by an examination of all the relevant circumstances. Significantly, according to her Ladyship, this includes "any advice or discussions at the time of transfer" (ie, the equivalent of express discussions pertinent to finding an express common intention in Lord Bridge's first category constructive trust) as well as "how the purchase was financed both initially and subsequently" (ie, the equivalent of financial contributions relevant in determining whether an inferred common intention exists in Lord Bridge's second category). The inescapable conclusion, it is submitted, is that the so-called "threshold question" enunciated in Rosset (ie, as to whether there is evidence from which to raise a common intention in the first place) has become largely superfluous given that the real (and only) question is simply to discern the parties' common intention by reference to all the relevant circumstances. $^{41}$

\section{JOINT OWNERSHIP CASES}

In cases where the property is purchased in joint names, equitable ownership will follow the legal title so the courts will presume that the parties intended to share beneficial entitlement equally unless the claimant's financial

${ }^{41}$ See Stack v Dowden [2007] UKHL 17, at para 59, per Baroness Hale. 
contributions (or improvements) to the property demonstrate a common intention that he (or she) is to have a greater or enlarged share.

In Stack itself, the presumption of joint beneficial ownership was displaced by the fact that the claimant had contributed substantially more to the acquisition of the property both in terms of the initial outlay to the purchase money and subsequent capital repayments on the mortgage loan. It was significant also that the parties had never pooled their separate savings and investments. This aspect, in particular, pointed strongly against equal sharing. Similarly, in Adekunle $v$ Ritchie $e^{42}$ the context of the purchase of the property was very different from that of a normal purchase in joint names. The purchase was of a council house by a tenant (the mother) with the benefit of a generous (50\%) discount. Her son was added to the purchase solely in order for her to be able to obtain a mortgage. The main reason for the purchase was to provide her with a home. As in Stack, the parties' finances were kept separate. All these factors together pointed to the conclusion that the parties did not intend a joint beneficial tenancy.

Significantly, however, the presumption of joint equitable ownership was upheld in the recent case of Fowler $v$ Barron $^{43}$ where the parties, an unmarried couple, bought a home in joint names without any formal declaration of trust or express discussions as to their beneficial entitlement. The male partner paid the deposit and the balance of the purchase price and acquisition costs. The mortgage was taken out in joint names, although the male partner paid all the mortgage instalments. The female partner, on the other hand, like the claimant in Burns, spent her income on herself and the children as well as on gifts, school clubs, trips and holidays. The Court of Appeal concluded that, following Stack, a presumption of joint beneficial ownership arose from the fact that the couple were joint legal owners. Although it was open to either party to rebut that presumption, the relevant intention to support a constructive trust had to be the parties' shared intention (actual or inferred) so that a secret (undisclosed) intention of the male partner (ie, that his female partner should only benefit in the event of his death and on the basis that they were still living together) had to be ignored. Moreover, the fact that the female partner had joined in the mortgage, notwithstanding that she was not expected to make any payment towards the discharge of the debt, was not inconsistent with the parties' shared intention that she should be a joint beneficial owner. Her nominal role, therefore, in relation to the mortgage could not by itself displace the presumption. Moreover, the amount of the parties' respective financial contributions was not decisive since:

42 (2007) WTLR 1505, Leeds County Court.

43 [2008] EWCA Civ 377. 
“...in a family context, many more factors than financial contributions may be relevant to define the parties' true intentions [including] ...the reasons why the home was acquired in the joint names, the purpose for which the home was acquired, the nature of their relationship and whether they had children for whom they had a shared responsibility to provide a home." 44

Critically, in this case, the fact that the parties had made mutual wills in each other's favour pointed strongly to the conclusion that each party was to have a half beneficial interest. This aside, however, the case does establish that a Burns-type claimant may become entitled to an automatic half share in the property (notwithstanding the absence of any significant financial contributions to acquisition) based solely on legal title being placed in joint names. As Arden LJ made clear in Fowler, "if the contrary [is] not proved, the mere fact that the property was transferred into their joint names [is] enough to give both parties an equal beneficial share." 45 Interestingly, Ms Fowler, like Mrs Burns, had contributed 19 years to the life and well-being of the family in a number of different ways. Unlike Mrs Burns, however, Ms Fowler was able to rely on her joint ownership of the home which automatically gave rise to a presumption of equal ownership in her favour. Again, in Rosset, had the parties purchased the property in joint names, then Mrs Rosset would have had no difficulty in establishing a constructive trust regardless of any contributions (trivial or otherwise) she may have made to the renovation works to the property. As in Fowler, she would automatically become entitled to half of the beneficial ownership.

\section{CONCLUSION}

The foregoing analysis suggests that the Burns claimant (i.e., one who has made no direct or indirect financial contribution towards acquisition or capital improvement of the property) will be able to claim a beneficial share by relying not only on a formal declaration of trust but also, alternatively, on an express common intention constructive trust.

In single ownership cases (in the absence of a formal declared trust), the common intention may arise from actual discussions between the parties regarding beneficial ownership coupled with conduct which amounts to an acting upon the common intention by the claimant. ${ }^{46}$ It is submitted that, in this context, contributions as homemaker will suffice to support the constructive trust. Applying the formula enunciated by Sir Nicholas Browne-

\footnotetext{
${ }^{44}$ Ibid, per Toulson LJ, at para 56.

${ }^{45}$ Ibid, at para 34.

${ }^{46}$ See Eves $v$ Eves [1975] 1 WLR 1388 and Grant v Edwards [1986] 1 Ch 638.
} 
Wilkinson in Grant, it is enough that the detriment relates to the joint lives of the parties and need not be referable to the property itself. In the inferred common intention category, however, orthodoxy would suggest that, in the absence of financial contributions towards acquisition, a Burns-type claimant would necessarily fail in satisfying the initial threshold hurdle enunciated in Rosset. $^{47}$ This requirement, however, now appears to have been the subject of judicial relaxation both by the House of Lords in Stack and, more significantly, the Privy Council in Abbott. Both these cases suggest a widening of the Rosset criteria necessary to support an inferred common intention constructive trust. Indeed, in Abbott, despite being a single ownership case, there is no mention of the two-stage inquiry of first, establishing and, secondly, quantifying the claimant's beneficial interest. The broad range of factors referred to in that case (ie, the husband's admission that his wife was entitled to a beneficial share, a shared gift from the husband's mother, joint liability on the mortgage and a joint bank account from which the loan repayments were made) appear to have sufficed for both establishing and quantifying the claimant's interest at the same time. This, of course, would mark a significant move away from the Rosset scheme and allow a Burns litigant to argue for a share in the home based on a much broader inquiry of her domestic and spousal contributions to the home and family. This, in turn, would allow for a much closer assimilation between single and joint ownership cases by the application of just a single composite test for the determination of the parties' common intention (either at time of purchase or subsequently) by reference to the whole course of dealing between the parties.

Indeed, it is submitted, that the claimant in Burns is no less deserving of a beneficial share than the litigant in Fowler. In both cases, the claimants had made no financial contribution towards acquisition, but instead provided significant domestic and spousal services to the home and family during the period of cohabitation. As in Burns, Ms Fowler spent her income on housekeeping expenses and the children with her male partner paying all the essential outgoings out of his own resources. Unlike Fowler, however, Mrs Burns did not keep her own money in a separate account but pooled it with the allowance she received from her partner. She also purchased fixtures and fittings, redecorated the whole house and paid for several consumer appliances including a dishwasher, washing machine and tumble dryer. Ms Fowler's expenditure, on the other hand, was limited to day-to-day costs on food, seasonal gifts, school clubs and trips, some personal clothing, holidays and special occasions. The fact of the matter is that, in the absence of the presumption that equity follows the law, Ms Fowler stands in no better

47 See most recently, James $v$ Thomas [2007] EWCA Civ 1212; Morris v Morris [2008] EWCA Civ 257 and Thomson v Humphrey [2009] EWHC 3576 (Ch). 
position than Mrs Burns in terms of her actual contributions to the home. In this sense, it can be said that she was no more deserving of an interest in the property than Mrs Burns save, of course, for the parties' notional intention to share equally arising from their legal ownership in joint names. In other words, the outcome in Fowler is different only because that is what the court infers to be the parties' common intention in joint ownership cases. Significantly, the same inference is not currently drawn in single ownership cases where the emphasis (in the absence of a declared trust or express discussions) is still on contributions of a capital nature only. Despite the potential broadening of the criteria relevant to determining the parties' common intention enunciated both in Stack and Abbott, the orthodox position (following Rosset) is that purely domestic contributions will not by themselves be enough to give rise to a common intention except where there have been previous discussions between the parties or the parties have entered into a formal declaration of trust. This must be the inevitable conclusion if Burns and Rosset continue to govern the law in this area.

Even if the Burns claimant is unable to rely on the mechanism of the constructive trust, it may still be possible to argue that the legal owner is estopped from denying the claimant's belief that he (or she) would be given a proprietary interest in the property. In fact, there are several English decisions in the context of property rights of married (and unmarried) couples where proprietary estoppel has been invoked to award the claimant an equity in the house in single ownership cases. A notable example is to be found in Maharaj $v$ Chand $^{48}$ where the female claimant, in reliance on her male partner's representations that the house would be a permanent home for her and the children, gave up her flat and used her earnings for household requirements and looked after the family. The Privy Council had no difficulty in holding that the claimant had established an estoppel equity to reside permanently in the property. In the absence, however, of any assurance on the part of the legal owner, the claimant would not have fared any better than the female litigant in Burns. ${ }^{49}$

There is currently a Cohabitation Bill in its $2^{\text {nd }}$ reading before Parliament. If the Bill becomes law, then a former cohabitant will be able to apply to court for a financial settlement order in relation to the parties' former family home. Although the claim will be based on status (rather than on the law of trusts), the court will be able to take a number of matters into account in determining whether to make an order, including (significantly) the contribution which each of the parties has made in the course of their living together as a couple, in particular, looking after the home or caring for any relevant child: clause 9(d)(i). Significantly also, the court will need to consider "any economic

\footnotetext{
48 [1986] AC 898, PC Contrast, Coombes v Coombes [1986] 1 WLR 808.

${ }^{49}$ See for example, Windeler $v$ Whitehall [1990] 2 FLR 505.
} 
disadvantage to which, in consequence of having lived together as a couple, each of the parties remains subject or is likely to remain subject in the foreseeable future": clause 9(f). This will, undoubtedly, have an important impact on the Burns claimant allowing the court, for the first time, to take into account on a statutory footing non-financial contributions as homemaker and child carer in determining beneficial entitlement. Whether the Bill actually becomes law, however, is yet to be seen. In the meantime, English law in this area continues to remain in a state of judicial flux. 